\title{
Extraction from subjects: some remarks on Chomsky's On phases
}

\section{Hans Broekhuis}

\section{Introduction ${ }^{1}$}

Chomsky (2005) has claimed that extraction from subject is possible when the subject is an internal argument (henceforth: derived subject), but not when it is an external argument (henceforth: underlying subject). This empirical claim is then employed to support the three theoretical claims in (1).

(1) a. C and $\mathrm{v}^{*}$, but not $\mathrm{T}$ or $\mathrm{V}$, are phase heads.

b. Phase heads have both Edge- and Agree-features, that is, they trigger both $\mathrm{A}^{\prime}$ - and A-movement (feature-inheritance theory).

c. Edge- and Agree-features of a phase head apply in parallel at the end of the phase.

Claim (1a) is familiar from Chomsky's earlier work and can in part be traced back to the barrier theory outlined in Chomsky (1986a). Claim (1b) amounts to saying that the $\varphi$-features on $\mathrm{T}$ and $\mathrm{V}$ are inherited from respectively $\mathrm{C}$ and $\mathrm{v}^{*}$ (the light verb associated with verbs that take an external argument); the fact that $\mathrm{T}$ and $\mathrm{V}$ do not inherently contain $\varphi$ features is given as a first reason for the claim in (1a) that these heads do not define a phase boundary. Claim (1c), finally, states that $\mathrm{A}^{\prime}$-movement does not attract the head of an A-chain, as was assumed in earlier proposals, but the foot. If a phase head triggers both $\mathrm{A}$ - and $\mathrm{A}^{\prime}$-movement, these movements proceed in parallel. This is indicated in (2) for the case of Wh-movement of the subject of the clause; recall that $\mathrm{T}$ can only attract the subject DP by virtue of inheriting the $\varphi$-features of C.

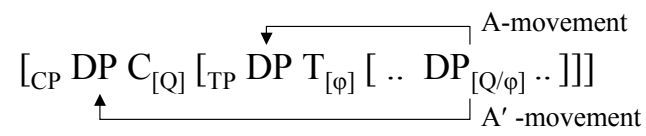

\footnotetext{
1 This research is made possible by the Netherlands Organisation of Scientific Research (NWO), grant 276-70-001, which is hereby gratefully acknowledged.
} 


\section{Hans Broekhuis}

This squib is organized as follows. Section 2 briefly discusses the data on which Chomsky bases his empirical claim and shows how the theoretical claims in (1) follow. Section 3 will argue that the examples used by Chomsky to support his empirical claim are suspect. Section 4 will provide a straightforward counterexample to this claim. From the fact that the empirical claim is clearly false, we must conclude that the theoretical claims in (1) are still not independently motivated. Section 5 will continue with explicitly arguing against assumption (1c) by showing that there are strong arguments against assuming derivations of the sort in (2). Section 6, finally, will provide a theory-internal argument against (1b).

\section{Chomsky’s proposal}

Chomsky (2005) claims that the traditional formulation of the subjectisland condition is too strict, and that it should be construed such that it prohibits movement from underlying subjects (external arguments) only. He provides the examples in $\left(3 a \& a^{\prime}\right)$ and $\left(3 b \& b^{\prime}\right)$ to show that extraction from a derived subject (internal argument) is as acceptable as extraction from a direct object; the unacceptability of the examples in $\left(3 c \& c^{\prime}\right)$, on the other hand, is taken to show that extraction from an underlying subject is blocked.

(3) a. It was the CAR (not the TRUCK) of which ${ }_{i}$ they found [DP the driver $t_{\mathrm{i}}$.

$\mathrm{a}^{\prime}$. Of which car ${ }_{\mathrm{i}}$ did they find [DP the driver $t_{\mathrm{i}}$ ]?

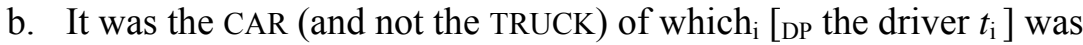
found.

$\mathrm{b}^{\prime}$. Of which car ${ }_{\mathrm{i}}$ was [DP the driver $t_{\mathrm{i}}$ ] awarded a prize?

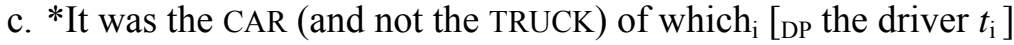
caused a scandal.

$\mathrm{c}^{\prime} .{ }^{*}$ Of which car $_{\mathrm{i}}$ did $\left[\mathrm{DP}\right.$ the driver $\left.t_{\mathrm{i}}\right]$ cause a scandal?

Extraction of the PP from the object DP in the transitive examples in $\left(3 a \& a^{\prime}\right)$ is assumed to proceed in the by now familiar fashion: the PP is first attracted by an Edge-feature on $\mathrm{v}^{*}$, as a result of which it is at the edge of the $\mathrm{V}^{*} \mathrm{P}$ phase; subsequently, it can be attracted by the next higher phase head $\mathrm{C}$ into SpecCP. Extraction from the subject in the passive examples in $\left(3 b \& b^{\prime}\right)$ proceeds in more or less the same way, although it might be that the PP is moved into SpecCP in one fell swoop because Chomsky assumes that the light verb $\mathrm{v}$ associated with passive and unaccusative verbs is not a 
phase head and therefore does not define a phase boundary. It is not so clear what causes the deviance of the extraction of the PP from the subject DP in the transitive examples in $\left(3 c \& c^{\prime}\right)$; the external argument is at the edge of the phase $\mathrm{v}^{*} \mathrm{P}$, and should therefore be accessible for the next higher phase head $\mathrm{C}$. Chomsky suggests, however, that $\mathrm{C}$ cannot attract the PP, because the latter is too deeply embedded in a phase already passed in the derivation (p.13/4 and p.19).

For the sake of the argument let us assume that this suggestion suffices to make the right distinction (although it doesn't seem to follow from any of the independently motivated constraints on movement). It is crucial that Chomsky's proposal presupposes that extraction of the PP from the subject does not apply from SpecTP. If that were the case, no distinction could be made between the b- and the c-examples in (3): these examples would then all have the structure in $(4 a)$, so that they would be predicted to have the same status. Rather, extraction should take place from the subject in its base position, as in (4b), so that the movement can be made sensitive to the question whether the subject occupies Specv*P or a VP-internal position.

(4) a.

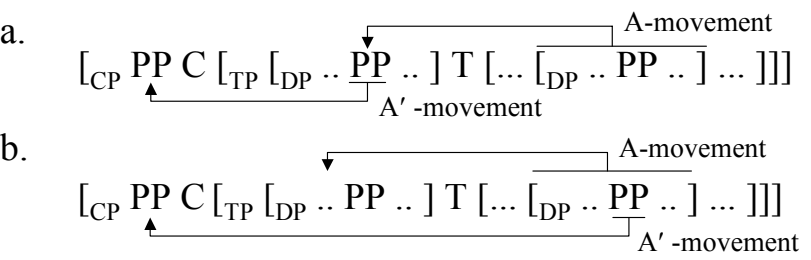

The assumptions in (1b\&c) are crucial to block the derivation in (4a) in favor of the one in (4b). Assumption (1c), according to which the A- and $\mathrm{A}^{\prime}$-movements triggered by a phase head (here: C) proceed in parallel, straightforwardly forces the derivation to proceed as in (4b): at the moment that $\mathrm{A}^{\prime}$-movement applies, the subject still occupies its base position. Assumption (1b) is also needed, because if we would assume that Thas $\varphi$ features independent of $\mathrm{C}$, (1c) would not be applicable and A-movement would still precede $\mathrm{A}^{\prime}$-movement, as in (4a). Finally, assumption (1a) is needed, because if T were a phase head, TP would be a phase and the PP would be 'too deeply embedded in a phase already passed in the derivation' in all examples in (3), so that they would all be predicted to be ungrammatical. 


\section{Hans Broekhuis}

\section{Extraction from subject?}

This section will argue that the examples in (3) do not support Chomsky's empirical claim. For my own convenience, I will use Dutch Topicalization examples to illustrate matters. First, it must be noted that constructions in (3) are of a very restricted sort in the sense that the allegedly extracted PP can only be headed by a limited set of prepositions. In Dutch this set is exhausted by van 'of' and over 'about'; PPs headed by, e.g., clearly locational prepositions are never extracted from DP. This is illustrated in (5) for extraction from object; (5b) is acceptable when the PP is construed as a locational adverbial phrase but not on its intended reading as a modifier of the noun huis 'house'. Chomsky's proposal, however, wrongly predicts the latter reading to be possible.

(5) a. Jan heeft het huis op de hoek gekocht.

Jan has the house on the corner bought

'Jan has bought the house on the corner'

b. *Op de hoek heeft Jan [DP het huis $t_{\mathrm{i}}$ ] gekocht.

Secondly, it is not so clear whether the van-PP in (6a) is really extracted from the object; under the right contextual and pragmatic conditions the object de eigenaar 'owner' can be replaced by a pronoun. Since pronouns normally resist modification, this suggests that the preposed van-PP does not function as a complement or a modifier of the noun, but rather as an independent adverbial phrase (cf. Broekhuis et al. 2003:258). Note in passing that the preposed van-PP in (6) triggers a contrastive reading, and that apparently the same holds for Chomsky's prime-less examples in (3).

(6) a. Van DEZE auto hebben ze de eigenaar nog niet gevonden of this car have they the owner not yet found (maar van DIE wel). but of that one AFF

b. Van DEZE auto hebben ze hem nog niet gevonden From this car have they him not yet found. (maar van DIE wel). but of that one AFF

A final piece of evidence in favor of the claim that the preposed van-PP is an independent adverbial phrase is that the preposed van-PP can be modified by a focus particle, whereas a postnominal van-PP cannot (cf. 
Broekhuis et al. 2003:257); if the preposed van-PP in (7a) originates from within the object DP, the ungrammaticality of (7b) would be very surprising.

(7) a. Alleen van DEZE auto hebben ze de eigenaar nog niet only of this car have they the owner not yet gevonden. found

b. *Ze hebben de eigenaar alleen van DEZE auto nog niet gevonden. they have the owner only of this car not yet found

Above I have given three arguments against the claim that the preposed PPs in (3) are extracted from the DP-arguments, and I suggested that these PPs are generated as independent adverbial phrases. Suppose, however, that one could successfully argue that the Dutch data in (5) to (7) can be accommodated under an extraction-from-DP analysis. Even then, I think, Chomsky's claim that extraction is only possible from derived subjects cannot be maintained, because it is actually quite simple to construct examples like (8), for which one might then claim that a van-PP is extracted from an underlying subject, and which would show then that the alleged contrast between derived and underlying subjects does not hold.

(8) a. Van DEZE fabriek hebben de werknemers gisteren het werk of this factory have the employees yesterday the work onderbroken. interrupted 'Of this factory, the employees interrupted their work yesterday.'

b. Van DEZE school hebben alle leerlingen verleden jaar of this school have all the pupils last year de marathon gelopen. the marathon run 'Of this school, all the pupils run the marathon last year.'

\section{Extraction from subject!}

The previous section has argued that Chomsky's alleged cases of extraction of PPs from a subject actually involve cases in which the PP functions as an independent adverbial phrase. This section will discuss a case that has traditionally been analyzed as involving extraction from argument, the socalled wat voor-split.. We will see that this split does not lend support to 


\section{Hans Broekhuis}

Chomsky's claim that extraction is possible from derived subjects only: extraction of wat from derived and from underlying subjects is equally (im)possible. My claim is perhaps surprising given that Den Besten (1985) has contended that wat voor-split is possible with direct objects and derived subjects $\left(9 a^{\prime} \& b^{\prime}\right)$, but not from underlying subjects $\left(9 c^{\prime}\right)$.

(9) a. Wat voor romans heeft hij geschreven?

what for novels has he written

'What kind of novels has he written?'

$\mathrm{a}^{\prime}$. Wat heeft hij voor romans geschreven?

b. Wat voor rare verhalen zijn (er) jouw vader verteld? wat for strange stories are there your father told 'What kind of strange stories have been told to your father?'

$\mathrm{b}^{\prime}$. Wat zijn (er) jouw vader voor rare verhalen verteld?

c. Wat voor mensen hebben je moeder bezocht? what for people have your mother visited 'What sort of people have visited your mother?'

$\mathrm{c}^{\prime}$.*Wat hebben voor mensen je moeder bezocht?

At first sight Den Besten's examples in (9) seem to support Chomsky's claim, but closer scrutiny quickly reveals that this is not really the case. The difference between $\left(9 b^{\prime}\right)$ and $\left(9 c^{\prime}\right)$ is not that the former contains a derived, whereas the latter contains an underlying subject, but is related to the position of the stranded part of the wat voor-phrase: in $\left(9 b^{\prime}\right)$ the stranded part is vP-internal, which is shown by the fact that it follows the indirect object jouw vader 'your father', whereas in $\left(9 \mathrm{c}^{\prime}\right)$ the stranded part is in the regular subject position, SpecTP. This is clear from the fact that when the remnant of $\left(9 b^{\prime}\right)$ occupies SpecTP, as in (10a), the result is as unacceptable as $\left(9 c^{\prime}\right)$. And if the remnant of $\left(9 c^{\prime}\right)$ is placed in $\mathrm{vP}$-internal position, as in the expletive construction in (10b), the result seems as acceptable as $\left(9 b^{\prime}\right){ }^{2}$

\footnotetext{
${ }^{2}$ I use the verb seem here because Den Besten actually claims that wat voor-split gives rise to a marked result in expletive constructions with an intransitive verb. So, Den Besten assigns "?*" to the example (ia). I do not agree with his judgment; to my ear, this example is fully acceptable. Furthermore, there is a very sharp contrast between the expletive construction in (ia), which we may assume to involve a subject in vP-internal position, and example (ib), in which the subject resides in SpecTP. In Broekhuis (1991/1992) I have given similar examples involving wat voor-split of subjects of transitive verbs (see also De Hoop and Kosmeijer, 1991, for similar judgments as reported here).
} 
(10) a. *Wat zijn voor rare verhalen jouw vader verteld?

b. Wat hebben er voor mensen je moeder bezocht?

The conclusion we have to draw from the discussion above is that, contrary to Chomsky's claim, extraction from subject is equally (im)possible from derived and underlying subjects, and hence that the theoretical claims in (1) are not independently motivated. Note that this conclusion is desirable, since, as was already noticed in the last paragraph in section 2 , the ban on extraction from underlying subjects actually does not follow from any independently motivated condition on movement.

\section{A- and $A^{\prime}$-movement do not proceed in parallel}

The fact that the theoretical claims in (1) are not independently motivated does not necessarily mean that they are incorrect. However, the fact that the assumptions (1b\&c) are only needed to derive Chomsky's false generalization on extraction from subject makes these assumptions highly suspect, so that they should be eliminated from the grammar. For stipulation (1c) we can even do better than applying Ockham's razor, and show that this assumption is simply false. For this, we only have to consider again the contrast between the prime-less and primed examples in (11), which are repeated from (9) and (10).

(11)a. Wat zijn (er) jouw vader voor rare verhalen verteld? what are there your father for strange stories told

$\mathrm{a}^{\prime}$. *Wat zijn voor rare verhalen jouw vader verteld?

b. Wat hebben er voor mensen je moeder bezocht? what have there for people your mother visited $\mathrm{b}^{\prime}$.*Wat hebben voor mensen je moeder bezocht?

In the expletive constructions in $(11 \mathrm{a} \& \mathrm{~b})$ the remnant of the wat voorphrase occupies a $v \mathrm{v} / \mathrm{v} * \mathrm{P}$-internal position, whereas in $\left(11 \mathrm{a}^{\prime} \& \mathrm{~b}^{\prime}\right)$ the remnant occupies the regular subject position. If the assumption in (1c) were correct, we would wrongly predict that the primed and prime-less

(i) a. Wat hebben er eigenlijk voor mensen geprotesteerd?

what have there actually for people protested

'What kind of people actually protested?'

b. *Wat hebben voor mensen eigenlijk geprotesteerd. 
examples in (11) have an equal status, the only difference being that the Amovement in (12) does not apply in the prime-less examples.

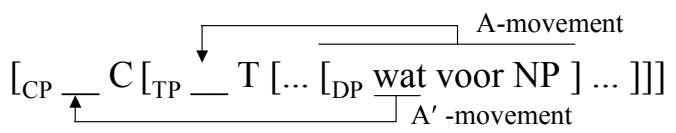

If movement of wat applies from the head of the A-chain, however, the desired distinction can be made: in the prime-less examples in (11), movement of the subject into SpecTP does not apply so that extraction of wat takes place from the $\mathrm{vP}$-internal position of the subject, as in (13a); in the primed examples, on the other hand, extraction of wat is preceded by Amovement of the subject, so that it takes place from SpecTP, as in (13b).

(13) a

a.

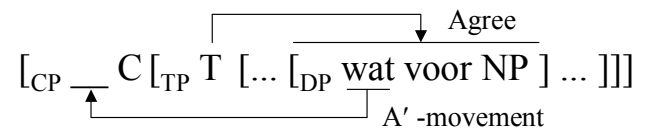

b.

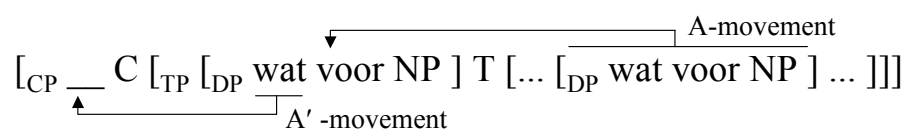

Thus, what we see in (11) is simply the effect of the traditional subjectisland condition; we therefore have to conclude that assumption (1c) cannot be part of the grammar. ${ }^{3}$

\section{Against feature-inheritance theory}

It cannot be argued in a straightforward way that the feature-inheritance theory (assumption (1b)) is false. However, when we assume that Kayne's (1994) universal base hypothesis, according to which all languages are SVO underlyingly, is correct, there are theory-internal reasons to reject this assumption. According to this proposal, the OV-order of languages like Dutch must be derived by means of leftward movement of the object across V. In Broekhuis (2000/2003) I have argued that this movement is triggered by the $\varphi$-features of $V$. If $V$ can only inherit these features from a phase

3 Of course, we still have to find a good minimalist account for the subject-island condition. See Chomsky (1995:328) for an attempt. Note in passing that the unacceptability of Chomsky's example (138), *who was [a picture of ] taken by Bill, is at odds with his 2005 claim that derived subjects are not islands for extraction, and supports the conclusion I arrived at in this squib. 
head (that is, from $\mathrm{C}$ or $\mathrm{V}^{*}$ ), we would predict that in passive and unaccusative constructions $\mathrm{V}$ does not have these features, because the light verb $\mathrm{v}$ in these constructions is not considered a phase head. Now consider the passive examples in (14).
(14)a. Morgen worden die boeken mijn oom $_{\mathrm{IO}}$ toegestuurd. tomorrow be those book my uncle prt.-sent
'The books will be sent to my uncle tomorrow.'
b. Morgen worden mijn oom $\mathrm{IO}$ die boeken S $_{\mathrm{S}}$ toegestuurd.
c. *Morgen worden mijn oom $\mathrm{IO}$ toegestuurd die boeken .

In (14a) the subject is simply moved into SpecTP; I have nothing special to say about this case in the present context. The crucial examples are given in $(14 b \& c)$. Example (14b) shows that the subject can follow the indirect object, which suggests that it is vP-internal. However, (14c) shows that the subject cannot occupy its base-position, but must be moved leftwards. If the $\varphi$-features of V are indeed responsible for this movement, this shows that $\mathrm{V}$ has $\varphi$-features. Therefore, if only phase heads can transmit $\varphi$-features and the light verb $\mathrm{v}$ in passive/unaccusative constructions is not a phase head, we must drop assumption (1b) and assume that the $\varphi$-features are intrinsically part of $\mathrm{V}$ (and, by extension, of $\mathrm{T}$ ).

\section{References}

Besten, Hans den. 1985. The ergative hypothesis and free word order in Dutch and German. In Studies in German Grammar, ed. Jindrich Toman, 23-65. Dordrecht/Cinnaminson: Foris.

Broekhuis, Hans. 1991. Chain-government. The Linguistic Review 6:297-374.

Broekhuis, Hans. 1992. Chain-government: issues in Dutch syntax. University of Amsterdam/HIL: PhD dissertation.

Broekhuis, Hans. 2000. Against feature strength: the case of Scandinavian object shift. Natural Language and Linguistic Theory 18:673-721.

Broekhuis, Hans. 2003. Subject shift and object shift. In Germania et alia: A linguistic webschrift for Hans den Besten, ed. Henk van Riemsdijk. http://odur.let.rug.nl/ koster/DenBesten/contents.htm.

Broekhuis, Hans, Evelien Keizer and Marcel den Dikken. 2003. Nouns and noun phrases. Modern grammar of Dutch. Occasional papers 4. Tilburg.

Chomsky, Noam. 1986. Barriers. Cambridge (Mass.): MIT Press.

Chomsky, Noam. 1995. The minimalist program. Cambridge (Mass.): MIT Press.

Chomsky, Noam. 2005. On phases. Ms. MIT. 


\section{Hans Broekhuis}

Hoop, Helen de, and Kosmeijer, Wim. 1995. Case and scrambling: D-structure vs S-structure. In Studies in comparative Germanic syntax, eds. Hubert Haider, Susan Olsen and Sten Vikner. Dordrecht/Boston/London, Kluwer Academic Publishers, 139-158

Kayne, Richard S. 1994. The antisymmetry of syntax. Cambridge (Mass.): MIT Press. 